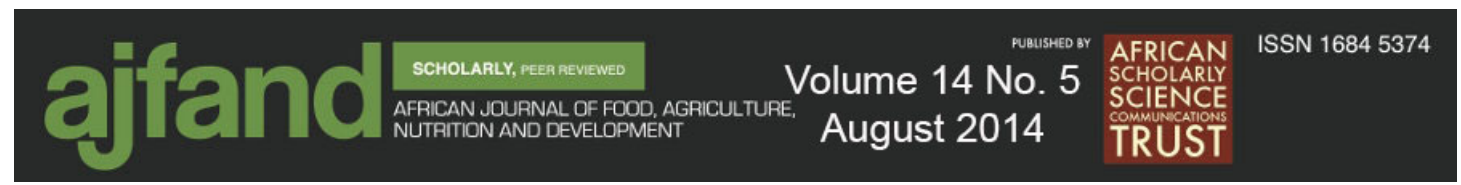

\title{
NUTRITIONAL ENHANCEMENT OF GHANAIAN WEANING FOODS USING THE ORANGE FLESH SWEETPOTATO (IPOMEA BATATAS)
}

\section{Bonsi EA ${ }^{1 *}$, Plahar WA ${ }^{2}$ and R Zabawa ${ }^{3}$}

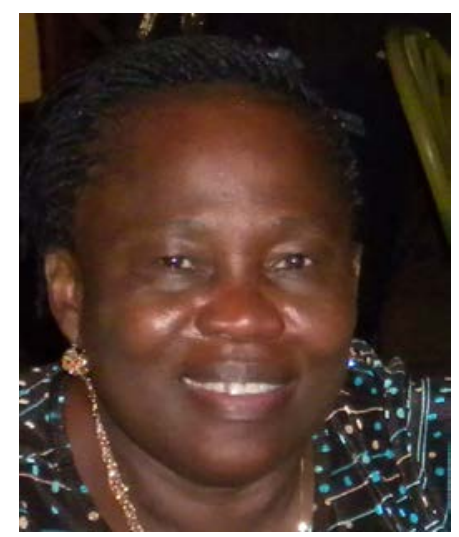

Eunice Bonsi

*Corresponding author email: ebonsi@mytu.tuskegee.edu

${ }^{1}$ Department of Foods and Nutritional Sciences and the Cooperative Extension Program, Tuskegee University, Tuskegee, Alabama

${ }^{2}$ CSIR, The Food Research Institute, Accra, Ghana

${ }^{3}$ The George Washington Carver Agricultural Experiment Station and the Cooperative Extension Program, Tuskegee University, Alabama 


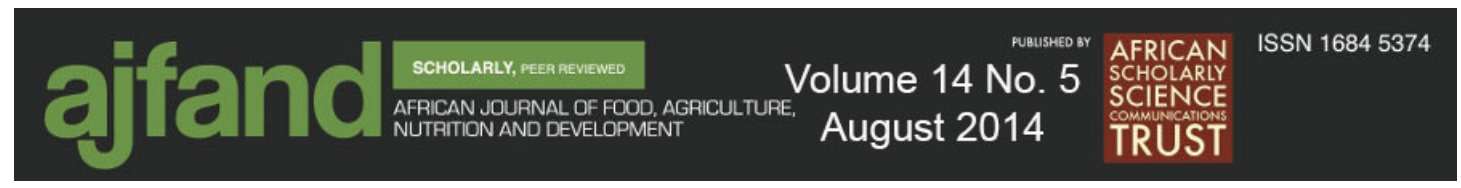

\begin{abstract}
Vitamin A deficiency (VAD) is a public health problem in Ghana. Research on the orange flesh sweetpotato root has been given prominence because of its high $\beta$ carotene content as a means to enhance the nutritive value and vitamin A content of the traditional diets of Ghanaian children as a long-term intervention towards combating VAD. Two Ghanaian cereal-legume weaning foods: roasted maize- soy blend and fermented maize-soy blend were added to Orange Flesh Sweetpotato (OFS) flour from the variety, Beauregard, to develop four weaning food formulations. To each product formulation preparation, 25\% and 50\% OFS flour was added to the basic cereallegume meals, and mixed thoroughly. The four weaning formulations were evaluated for chemical composition, sensory characteristics and consumer acceptability. All samples had a range of protein $(12.1 \%$ - 15\%), fat ( $4.8 \%$ - 6.4\%), carbohydrate $(71.1 \%-75.1 \%)$, energy (380 - $390 \mathrm{kcal} / 100 \mathrm{~g}$ ) and minerals (calcium, iron and phosphorus) to ensure good nutrient density, while the moisture content was low $(5.3 \%-6.1 \%)$ for storage stability. The contribution of $\beta$-carotene $(55.18-115.55 \mathrm{ug} / \mathrm{g})$ by the OFS in the formulations further enhanced the nutritive value of all the blends and is enough to meet the daily $\beta$-carotene needs of the children (1-6 yrs of 400-450ug/100g). A higher level of $\beta$-carotene was seen in the roasted maize meal weaning foods which makes them a better potential blend for combating VAD. Also, sensory evaluation of the products indicated the highest consumer acceptability score (87\%) for the roasted maize meal porridge formulation containing $25 \%$ OFS. It is, therefore, concluded that OFS flour has the potential to be used at $25 \%$ replacement level in the soy-fortified roasted maize meal formulation, and OFS is a useful ingredient with the potential to improve the $\beta$-carotene or vitamin A content of such formulations. This will help alleviate vitamin A deficiency of children in Ghana and other countries with similar problems. It is, therefore, recommended that the orange flesh sweetpotato flour be used by mothers as an entry point for enhancing the traditional weaning food preparations.
\end{abstract}

Key words: $\beta$-carotene, sweetpotato flour, weaning foods 


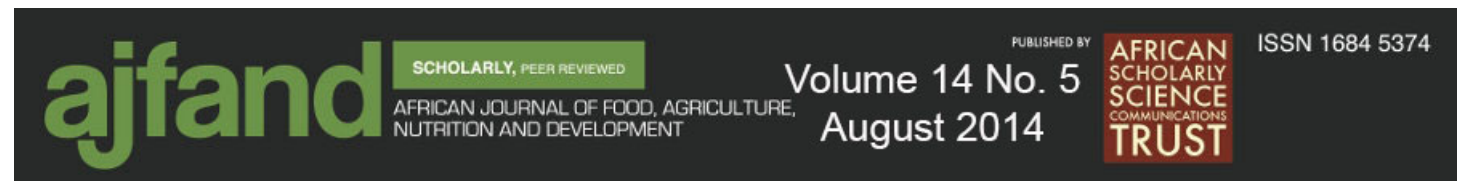

\section{INTRODUCTION}

The major micronutrient deficiencies of public health concern in Ghana are Vitamin A, iron, iodine and zinc [1]. Vitamin A deficiency (VAD) is a public health problem in most developing countries, being an important cause of blindness especially in children, pregnant and lactating women [1]. It is, thus, a priority in health policy to improve preformed vitamin A and/or pro-vitamin A carotenoid status in these children. The effective use of readily available and inexpensive sources of micronutrients has become a major focus of research in recent years. While breastfed infants are often able to maintain adequate growth through their sixth month, additional nutrients are required to complement or, in some cases, replace breastfeeding completely. Traditionally, weaning foods in the form of liquids and semisolids are fed to 6-9 months infants and later replaced by foods eaten by older family members. Most of the time these types of foods can be filling and yet not meet children's nutrient needs. Nutritional status in children is most vulnerable during the weaning stages when both macro and micronutrients may be insufficient to maintain growth and development [2]. Protein-energy malnutrition and micronutrient undernutrition usually occur together; therefore, the main concern is making sure that there is no gap between nutrient requirements and what a child is able to consume, absorb, and utilize [3]. Infant malnutrition, underweight and stunting has increased efforts in research, development, and extension by both local and international organizations to improve the energy and protein content of weaning foods specifically primary traditional fermented maize meal only or roasted maize meal only weaning foods which had been attributed to the high prevalence of child malnutrition for infants in Ghana [3]. The addition of soybean flour to the traditional formulation (Weanimix) has improved its protein quality but not the vitamin A status [3]. Combating vitamin A deficiency in populations in developing countries, and especially in children, is a key component of the World Food Summit's 1996 goal to cut the number of the world's under-nourished people in half by 2015 [4].

Infants, young children and pregnant women, especially in low-income countries, are more susceptible to VAD because of undernutrition, consumption of low vitamin Arich foods, and infectious diseases such as diarrhea and measles. In Ghana, almost three-quarters of children aged 24 to 59 months suffer from sub-clinical vitamin A deficiency and 35 percent suffer from severe vitamin A deficiency [5].The main causes of VAD in Ghana are unavailability and limited consumption of meat, eggs and dairy products, and fruits and vegetables rich in vitamin A [5]. In 2006, 60 percent of Ghanaian children and 55 percent of mothers had their diets supplemented with vitamin A capsules [5]. While this "medical perspective" has been a widespread and often import dependent, there is support for community or farming systems approach of local food-based vitamin A-rich products [6].

Research on the orange flesh sweetpotato root has been given prominence because of its high $\beta$-carotene content as a means to enhance the nutritive value of the traditional diets of Ghanaian children [7]. Sweetpotato is an indigenous food crop that can be produced on marginal soils and under adverse climatic conditions and thus lends itself 
to low input agriculture and satisfies more nutritional requirements. Ghanaian sweetpotato varieties have roots with either white- or cream-colour flesh [7]. Varieties released in 2005, however, have increased levels of $\beta$-carotene and range from yellow- to orange-colour flesh. These new varieties have the potential to address vitamin A deficiency. Successful utilization and acceptability of the orange flesh sweetpotato for weaning food depend on creating culturally acceptable sweetpotato blends or products. Previous efforts by researchers to improve the nutritional status of infants in Ghana and other African countries were focused mainly on providing adequate protein in infant formulas through utilization of inexpensive and readily available plant protein sources such as soybean [8]. Not much attention was given in the past to the enhancement of vitamin A from plant-based dietary sources [8]. Recent research has shown that just one small root (100-125 grams) of most orange flesh sweetpotato varieties can supply the recommended daily allowance of vitamin A for children under five years of age [9]. An example of such food-based approach to combatting VAD with orange flesh sweetpotato has been found to increase Vitamin A intake and serum retinol concentrations in children in rural Mozambique [10]. Sweet potato (presumably, the orange colour varieties) was mentioned in the GDHS Reports as one of the food sources rich in vitamin A that can be promoted for consumption by infants between 6 to 9 months $[11,12]$. These findings, coupled with the fact that sweet potato is less laborious to cultivate than cereals present sweet potato as a suitable choice for processing a dried blend of complementary food [13, 14].

Cereal-legume blends have been found to be relatively high in protein (both quality and quantity) because the legumes supply the lysine cereals lack. While the cereals provide cysteine and methionine which are low in legumes soybeans have been used in making the roasted or fermented cereal into such a complimentary mix [2]. However, research findings indicate that cereal-legume porridge without fortification with vitamin and mineral supplements can lead to deficiency of micronutrients such as iron and vitamin A among infants because such foods are low in vitamin A. Also, vitamin and mineral supplements are not readily available for use by families at households in Ghana due to cost. Sweet potato-fortified weaning food blends which could be processed industrially (using either extrusion cooking or roller drying) or at the household-level (using toasting in an oven or open-pan) are proposed [2]. This research was, therefore, to determine proportions of orange flesh sweetpotato flour that can be acceptable in a cereal-legume blend of maize fortified with soybeans. Using orange flesh sweetpotato as part of the main ingredients in the formulation of weaning foods will make such infant formulas nutritionally more complete and help address the vitamin A deficiency problem. Process optimization and standardization for effective value addition and enhanced sensory attributes were the main focus in the blend formulation efforts. An easy-to-adopt strategy by most households in Ghana and probably in low-income countries would be to replace some of the ingredients in the cereal-legume food mix with orange flesh sweet potato (Ipomoea batatas).

Weanimix, a cereal-legume blend of maize and soybean flour has been reported to have an energy value of $1820 \mathrm{~kJ} / 100 \mathrm{~g}$ and protein level of 15/100 g compared to a maize meal-only porridge, which has energy value of $100 \mathrm{~kJ} / 100 \mathrm{~g}$ and protein level 
of $0.6 / 100 \mathrm{~g}[15,16]$. At the same time there is evidence that Weanimix is inadequate to meet the demand for vitamin A, iron or zinc $[15,17,18]$. Hence, Weanimix formed the premise of our study to which OFS flour is added.

\section{MATERIALS AND METHODS}

\section{Materials}

Orange flesh sweetpotato (OFS) flour prepared from the newly released United States (Beauregard) sweetpotato variety was obtained from Selasie Farms Ltd., Accra, Ghana, and used as one of the major ingredients for all the weaning food formulations. Other ingredients used for the weaning food formulations included maize (Zea mays), and full fat soybeans (Glycine max). These were obtained from local grain markets in Accra, Ghana and descriptions of their processing methods follow (Figure 1).

\section{Methods}

\section{Processing of ingredients used in weaning food formulations}

Raw grains were first cleaned separately by removing extraneous materials and then sorted. Flours of the various ingredients - roasted maize, soybeans, and dehydrated fermented maize - were all prepared individually by standard methods developed at the CSIR-Food Research Institute [2, 8, 19, 20]. Cleaned maize samples were roasted separately in a gas heated pan roaster equipped with a mechanical stirrer (FATECO, Ghana Ltd.) maintained at $150^{\circ} \mathrm{C}$ for one hour. The roasted maize was milled into flour in a disc attrition mill. Samples of full-fat soybean flour and dehydrated fermented maize meal were prepared by the method of Plahar et al. [20]. Cleaned soybeans were soaked in water for one hour and boiled for 20 minutes. The boiled soybeans were dried in a hot air oven, de-hulled and milled in a disc attrition mill (No. 2A Premier Hunt Type). Dehydrated fermented maize meal was also prepared by the method described by Annan and Plahar [2]. Maize grains were soaked for 24 hours, washed and milled. The meal was mixed with water and kneaded into smooth dough of about $50 \%$ moisture content. The dough was allowed to ferment spontaneously at ambient temperatures for three days after which the fermented dough was dried in a cabinet dryer maintained at $60^{\circ} \mathrm{C}$ and milled (Figure 1). Orange sweetpotato roots were cleaned, peeled, sliced and washed in cold water. Water was drained and slices were blanched or dipped in boiling water for five minutes, drained and spread in solar drier to dry. Dried chips were milled into flour using the very fine grade sieve of the Hammer Mill and packaged in for use (Figure 2). For each weaning food blend preparation, appropriate portions of the various flours were weighed separately and mixed thoroughly. 

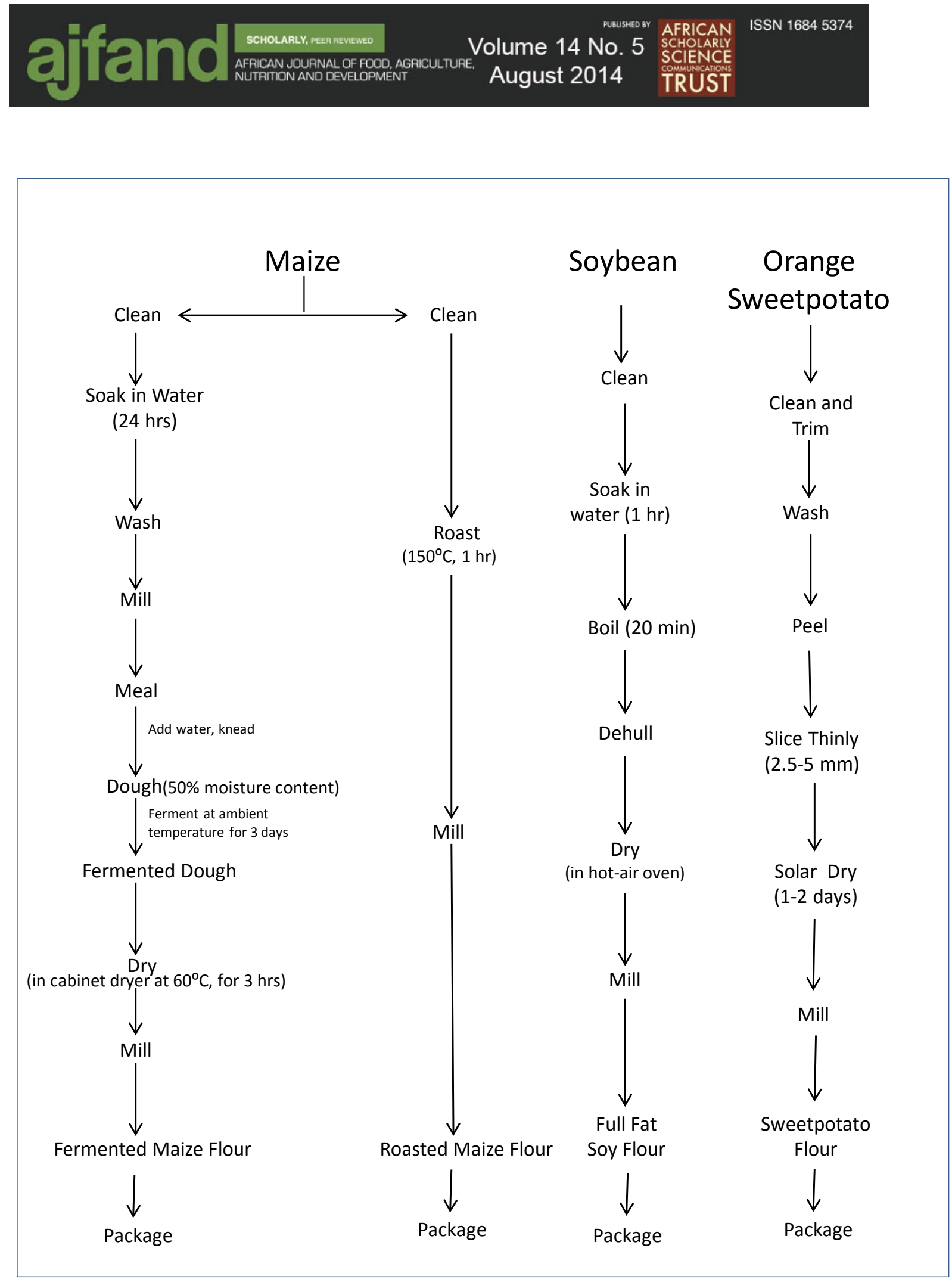

Figure 1: Flowchart for processing the raw ingredients used in the weaning foods Source: modified from $[2,8,19,20]$ 


\section{Orange Sweetpotato}

Roots

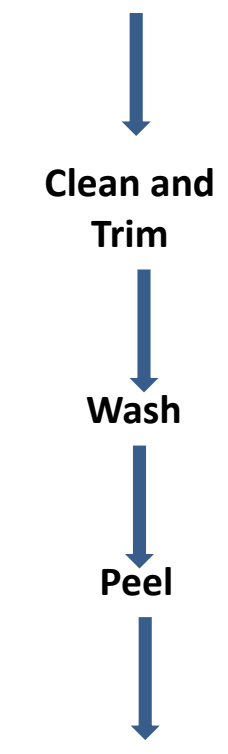

Slice Thinly

(2.5-5 mm)

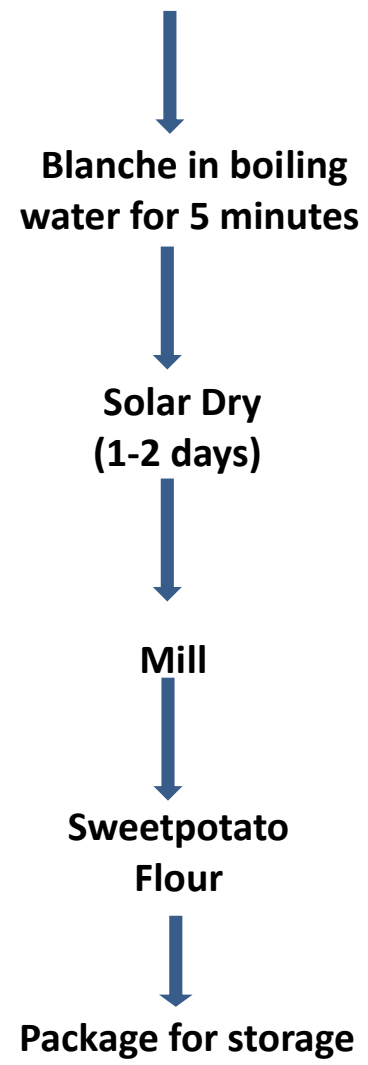

Figure 2: Flowchart for processing the raw orange sweetpotato used in the weaning food formulation

Source: modified from [21] 


\section{Blend formulation and product development}

Orange flesh sweetpotato (OFS) flour from the variety, Beauregard, was used to develop four weaning food formulations based on the roasted maize meal (popularly known as "Tom Brown") plus soybean and fermented maize meal (popularly known as "koko") plus soybean weaning foods. Two products each, with 25\% and 50\% OFS flour, were developed-roasted maize meal-soybean $+25 \%$ OFS flour (Tomvita 25), roasted maize meal-soybean $+50 \%$ OFS flour (Tomvita 50), fermented maize mealsoybean $+25 \%$ OFS flour (Mayvita 25) and fermented maize meal-soybean $+50 \%$ OFS flour (Mayvita 50). Each product blend preparation was mixed thoroughly and the four weaning formulations were evaluated to achieve desirable chemical, physical, functional and sensory characteristics with the maximum possible level of OFS flour. The normal product development phases involving idea generation, screening of ideas, technical development processes for optimization and prototype refining by sensory techniques, were applied in the development of the new weaning foods. Major factors considered and evaluated in the product development process included the optimization of OFS flour to enhance $\beta$-carotene content of the cereal-legume blend, as well as the effects of the relative concentration of the various ingredients, on the general quality, especially the nutritional and sensory characteristics, of the final products.

\section{Chemical quality evaluation}

Moisture (AOAC 925.10), protein (AOAC 984.13), fat (AOAC 920.39) and ash (AOAC 923.03) were determined by the AOAC standard methods while iron, calcium and phosphorous were determined by AACC bipyridyl colourimetric, permanganate titration, and molybdenum methods, respectively [22, 23]. Carbohydrate was determined by difference (100 - Sum of \% moisture, \% protein, \% fat and \% ash). Energy values were obtained using the Atwater factors 4, 9 and 4.00 for protein, fat and carbohydrate, respectively [24]. Beta-carotene was analyzed using standard procedures. Samples (1 g) were extracted with $25 \mathrm{~mL}$ 7:3 hexane: acetone mixture. The extract was filtered and the residue rinsed until sample became colourless. The filtrate was transferred into a separator funnel and washed with $50 \mathrm{~mL}$ of distilled water. The water phase was discarded and the extract dried with $10 \mathrm{~g}$ anhydrous $\mathrm{Na}_{2} \mathrm{SO}_{4}$. The extract was then made up to $50 \mathrm{~mL}$ and the absorbance read at $450 \mathrm{~nm}$. Proximate composition and mineral of the blends were compared to the previously analysed maize-meal-soybean cereal blend (Table5).

\section{Sensory evaluation}

Sensory preference for the OFS-based weaning foods was evaluated using cooked porridges prepared from the weaning food samples. For each weaning food, coldwater slurry was prepared (100 g sample in $200 \mathrm{~g}$ water) and stirred into $200 \mathrm{~g}$ boiling water. The mixture was allowed to boil for $5 \mathrm{~min}$ while stirring and with the gradual addition of another $100 \mathrm{ml}$ water to achieve the desired consistency. The samples were served at $40^{\circ} \mathrm{C}$ to members of a taste panel consisting of workers at the CSIRFood Research Institute. A 15-member trained panel of judges was used in the laboratory sensory tests. Ethical approval for the sensory evaluation was obtained 


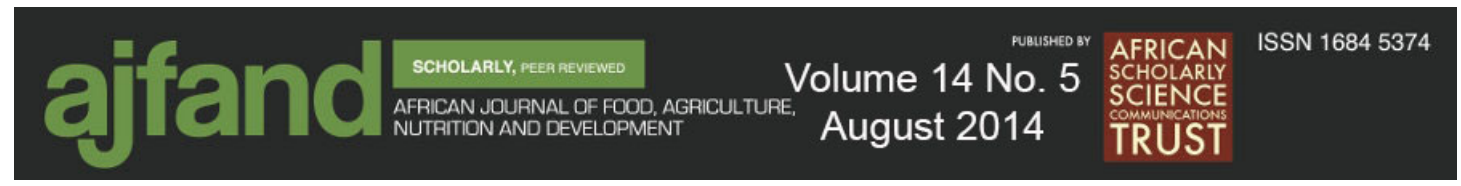

from the Food Research Institute. The preference test was conducted using a ninepoint Hedonic scale of $1=$ dislike extremely; $2=$ dislike v. much; $3=$ dislike moderately; 4= dislike slightly; $5=$ indifferent; $6=$ like slightly; $7=$ like moderately; $8=$ like v. much; $9=$ like extremely to determine relative preferences for the various sensory attributes of appearance, colour, aroma, taste, mouth feel and overall acceptability [25]. To determine whether there were any detectable differences between the OFS enhanced roasted maize meal weaning foods and the fermented maize meal porridges, the triangle test was used [25].

\section{Statistical analysis}

Statistical Analysis System (SAS) computer software (version 8.2; SAS Institute, Cary, NC, 2001) was used in the analysis of data. Statistical parameters with repeated measures analysis of variance was generated which allows the treatment variances to be different between the blends

[26]. Differences between means were evaluated by the least significant difference (LSD) test. Significance was accepted at $p<0.05$. For the analysis of the sensory evaluation data, the probability associated with the Student's t-test was calculated to determine significance of observed differences.

\section{RESULTS}

\section{Blend formulation and product characteristics}

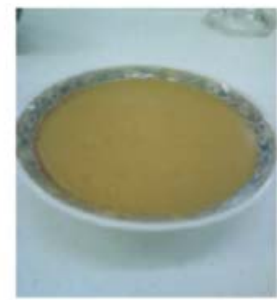

TOMVITA 25

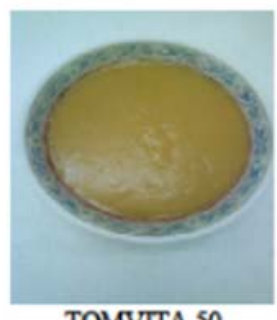

TOMVITA 50

Figure 3: Sample of roasted maize meal porridge containing 25\% (TOMVITA 25) and $50 \%$ (TOMVITA 50) Orange Sweetpotato flour

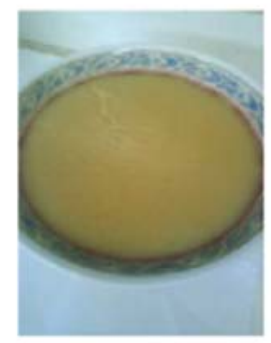

MAYVITA 25

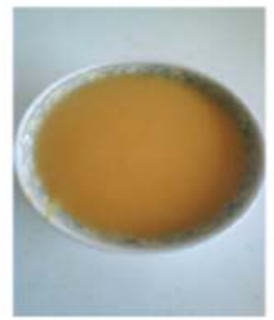

MAYVITA 50

Figure 4: Sample of roasted maize meal porridge containing 25\% (MAYVITA 25) and 50\% (MAYVITA 50) Orange Sweetpotato flour 
Prior research analysis of the chemical components of two weaning foods by [2] showed that the Weanimix scored higher in most micronutrients as compared to the roasted maize meal, and was highly acceptable in sensory evaluations (Table 1). The ingredient formulations and physical product characteristics of the weaning food blends as perceived by the selected expert panel are shown in Table 2. The 'Tomvita' formulas are the roasted maize meal weaning food while the 'Mayvita' formulas are the fermented maize meal weaning food. The differences in colour among the different formulations are shown in Figures 3 and 4.

\section{Sensory characteristics}

Table 3a shows the results of triangle difference tests conducted on the OFS-based weaning foods. The degree of difference was from much-to-very much in all cases, except the 25\% OFS-roasted maize meal blend which recorded a slight difference. Table 3b gives the individual mean sensory scores for the various sensory characteristics of porridges prepared from the OFS-based weaning foods. The overall acceptability scores, degree of liking, and the limiting sensory factors are summarized in Table 4. Roasted maize meal based weaning foods containing 25\% OFS were the most acceptable products, with the highest overall acceptability score of 8.2 (indicating 'like very much') recorded for the 25\% OFS formulation (Table 4). At 50\% levels of OFS, however, the overall acceptability scores of the roasted maize meal-based weaning foods reduced to 'like moderately'. The most significant adverse effect of high (50\%) levels of OFS in the roasted maize meal-based formulations was on the taste and aroma, which reduced the overall acceptability drastically. Here, mean sensory scores and hence, the degree of liking for sensory attributes, such as appearance, colour, consistency and mouth-feel, did not change significantly ( $>0.05$ ) with increased levels of the OFS from $25 \%$ to $50 \%$. The mean scores for these sensory attributes still remained high ('like very much') in the $50 \%$ OFS samples. At both 25\% and 50\% levels of OFS in the fermented maize meal formulations, overall acceptability of the porridge was scored as 'like moderately'. Taste, aroma and mouthfeel were the sensory attributes that were given the lowest acceptability scores, and were thus the limiting sensory attributes (Table 4).

\section{Chemical composition of OFS-based weaning foods}

Table 5 shows the proximate composition and mineral and beta carotene content of OFS fortified weaning foods as compared to maize-soybean only, previously analyzed by Annan and Plahar [2]. The moisture content of the products (ranging from 5.26\% to $6.07 \%$ ) is low enough to facilitate long storage shelf-life. The highest protein content of 15.02 percent was obtained for the 25\% OFS fermented maize meal weaning food, followed by the $25 \%$ OFS roasted maize meal weaning food (14.97\%). With respect to minerals, calcium content of blends decreased with the addition of OFS, while phosphorus, iron and beta carotene increased. At elevated levels of OFS (50\%), the protein and fat contents decreased significantly $(\mathrm{p}<0.05)$, while no significant changes were observed in the ash. In sum, the maize meal - soybean only weaning food scored higher in protein, fat, calcium and phosphorus, the sweetpotato flour fortified cereal legume based weaning food score higher in ash, carbohydrate, iron and $\beta$-carotene. 


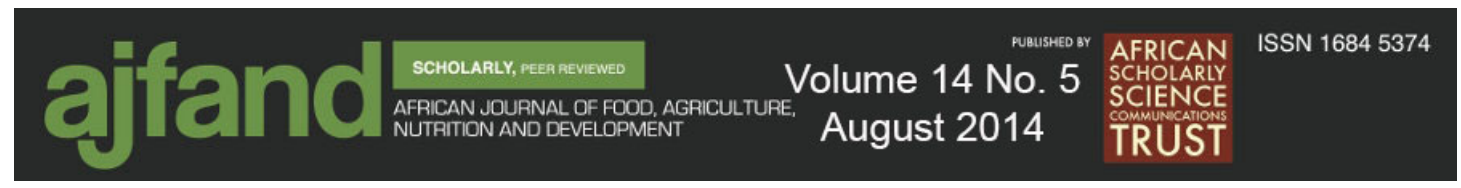

\section{DISCUSSION}

\section{Blend ingredient formulation and product characteristics}

Colour is an important sensory evaluation factor for acceptance when coupled with taste and texture (mouth-feel). Consumers often assess initial quality of foods by colour and appearance, which affects perceptions of other attributes, such as aroma, taste, and flavor. Even though children may not determine assessment on the weaning food, parents often determine sensory attributes on their behalf. As the percentages of OFS increased, the dislike for colour and after taste increased.

\section{Sensory characteristics}

In spite of the differences, the two samples containing 25\% OFS in the roasted maize meal-based weaning foods were more acceptable to the panel over the existing other ones. At 50\% level of OFS, the fermented maize meal -based product was preferred over the roasted meal-based product by the taste panel. The two OFS-fermented maize meal samples were said to have a poor taste and an off-flavour. The colour imparted by the addition of the OFS was also highly unattractive to the taste panel in the fermented maize meal porridges.

In general, formulations with 25\% OFS in roasted maize meal based weaning foods were more acceptable than in the fermented maize meal foods that recorded mean scores indicating a moderate degree of liking for the product. Very low overall acceptability scores were recorded for OFS formulations based on the traditional fermented maize meal weaning food. This is perhaps due to the peculiar nature of the sensory characteristics of the fermented maize meal porridge, which is produced by lactic acid fermentation. In this case, distortions in the natural acidity of the product by other additives could affect the taste significantly.

\section{Chemical composition of OFS-based weaning foods}

Owing to the mutual complementation of the limiting amino acids in maize and soybeans, these formulations are not only high in protein content but also have high protein quality [19]. Earlier studies by Plahar et al. [20] established the improved amino acids balance when soybeans are added to weaning blends containing roasted or fermented maize meals. For the roasted maize meal formulations, the most significant effect of soybeans in the blend formula was the increase in fat and protein content, with corresponding decrease in the carbohydrate content. The energy value of the blend is also increased significantly by the addition of soybeans to the blend formulation.

Periodic oral supplementation and food fortification have had documented success and have established their merit in preventing nutritional blindness, but they are considered expensive, temporary solutions. Bio-fortification of staple weaning foods such as maize meal and millet flour with local sources of pro-vitamin A carotenoids enhances vitamin A status [27]. Among the benefits of promoting such local plantbased vitamin and other micronutrient food sources is that they provide concurrent intake of other nutritive and non-nutritive substances that contribute to the prevention of disease [27]. 


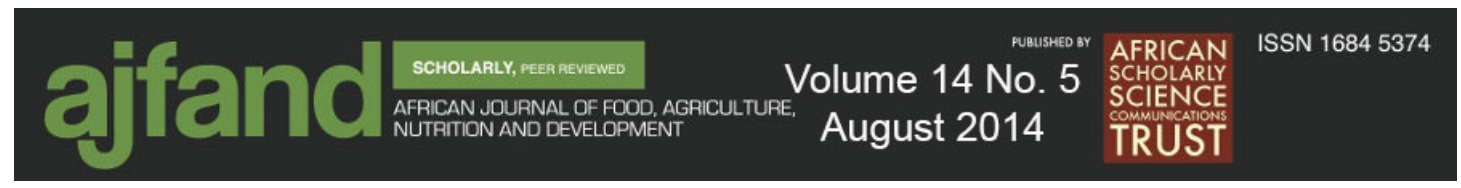

\section{CONCLUSION}

The OFS flour can be used at 25\% replacement levels with maize, in the formulation of highly acceptable, good quality weaning foods based on the soy-fortified traditional Roasted maize meal (roasted maize meal porridge) to help alleviate macro- and micro-nutrient malnutrition problems in Ghana and other West African countries. The obvious contribution of high levels of $\beta$-carotene makes OFS a useful ingredient with the potential to improve the vitamin A content of such blends. Dietary diversity of entire families to include natural food sources rich in pro-vitamin A may provide the long-term solution to preventing VAD in developing countries because orange flesh sweetpotatoes and other indigenous leafy vegetables rich in $\beta$-carotene can be easily grown as gardens in communities, making sources sustainable and cheaper compared to periodic oral dosing with vitamin A. Preparation of blend demonstration as a weaning food and encouraging women to include the orange flesh sweetpotato as vegetables in their diets could be an important strategy to improve vitamin A status. There is the need to identify and acknowledge the orange flesh sweetpotato nutritional value due to its potential to help mitigate micronutrient deficiencies. These formulations would satisfy the requirements for energy, protein and fat specified in the Codex Alimentarius Commission guidelines (CODEX) and also be a better source of $\beta$-carotene [28]. The study could have included the Weanimix porridge for comparative evaluation at the same time of evaluating the blends. Therefore it is recommended that this be done for the enhancement of the study.

\section{ACKNOWLEDGEMENTS}

This research is made possible by the generous support of the American people through the United States Agency for International Development (USAID). The contents are the responsibility of the Feed the Future Innovative Lab for Horticulture project, "Nutritional and Economic Enhancement of Ghanaian Traditional Diets Using Orange Flesh sweetpotato (OFS) Products.” The authors sincerely extend their heartfelt appreciation to Dr. Elizabeth Chibozo, a visiting scientist to Tuskegee University for her professional thorough review and critique of this manuscript. They thank the George Washington Carver Agricultural Experiment Station, Tuskegee University, Alabama, and Center for Scientific and Industrial Research (CSIR) for their support. Finally, the assistance of local women, communities, small business owners and farmers in the Volta and Tamale regions are very much acknowledged. 


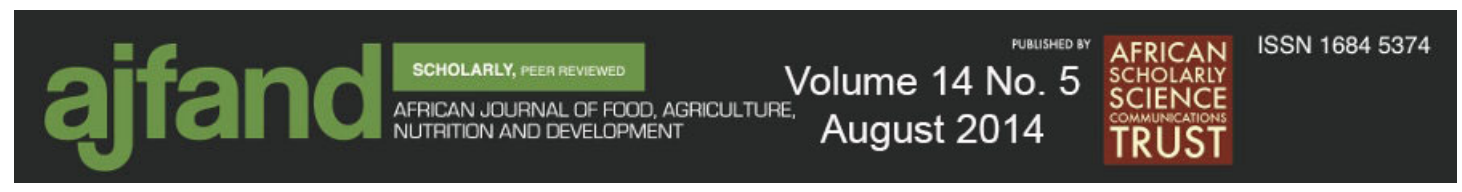

Table 1: Chemical composition of weaning foods ${ }^{1}$

\begin{tabular}{|l|l|l|}
\hline \multirow{2}{*}{ Component } & \multicolumn{2}{|c|}{ Weaning foods } \\
\cline { 2 - 3 } & $\begin{array}{l}\text { Roasted maize meal } \\
\text { (Tom Brown) }\end{array}$ & $\begin{array}{l}\text { Weanimix } \\
\text { (legume-based) }\end{array}$ \\
\hline Moisture (\%) & 2.32 & 2.56 \\
\hline Protein (\%) & 9.60 & 17.10 \\
\hline Fat (\% ) & 4.30 & 10.56 \\
\hline Ash (\%) & 1.39 & 1.98 \\
\hline Carbohydrates (\%) & 82.40 & 67.80 \\
\hline Energy (kcal) & 406.62 & 442.60 \\
\hline Iron (mg/100 g) & 3.60 & 4.50 \\
\hline Phosphorus (mg/100g) & 369.70 & 374.40 \\
\hline Calcium (mg/100 g) & 139.15 & 253.50 \\
\hline Overall acceptability ${ }^{\mathrm{a}}$ & 7.5 & 8.2 \\
\hline
\end{tabular}

1Source: [2]

Values are means of triplicate determination and used as a frame of reference for the formulation

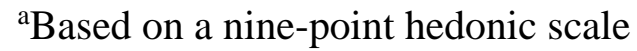




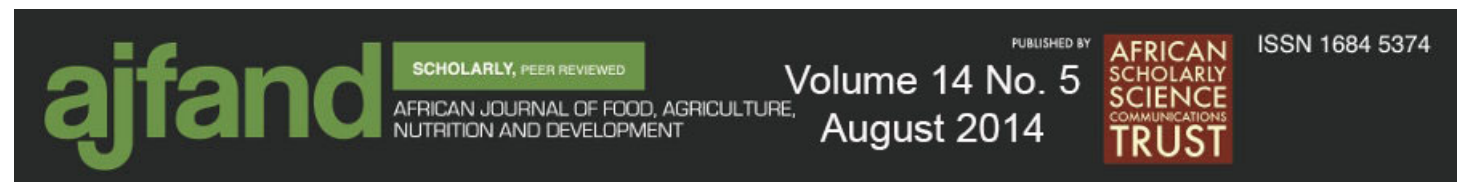

Table 2: Ingredients formulation and product characteristics of weaning food blends

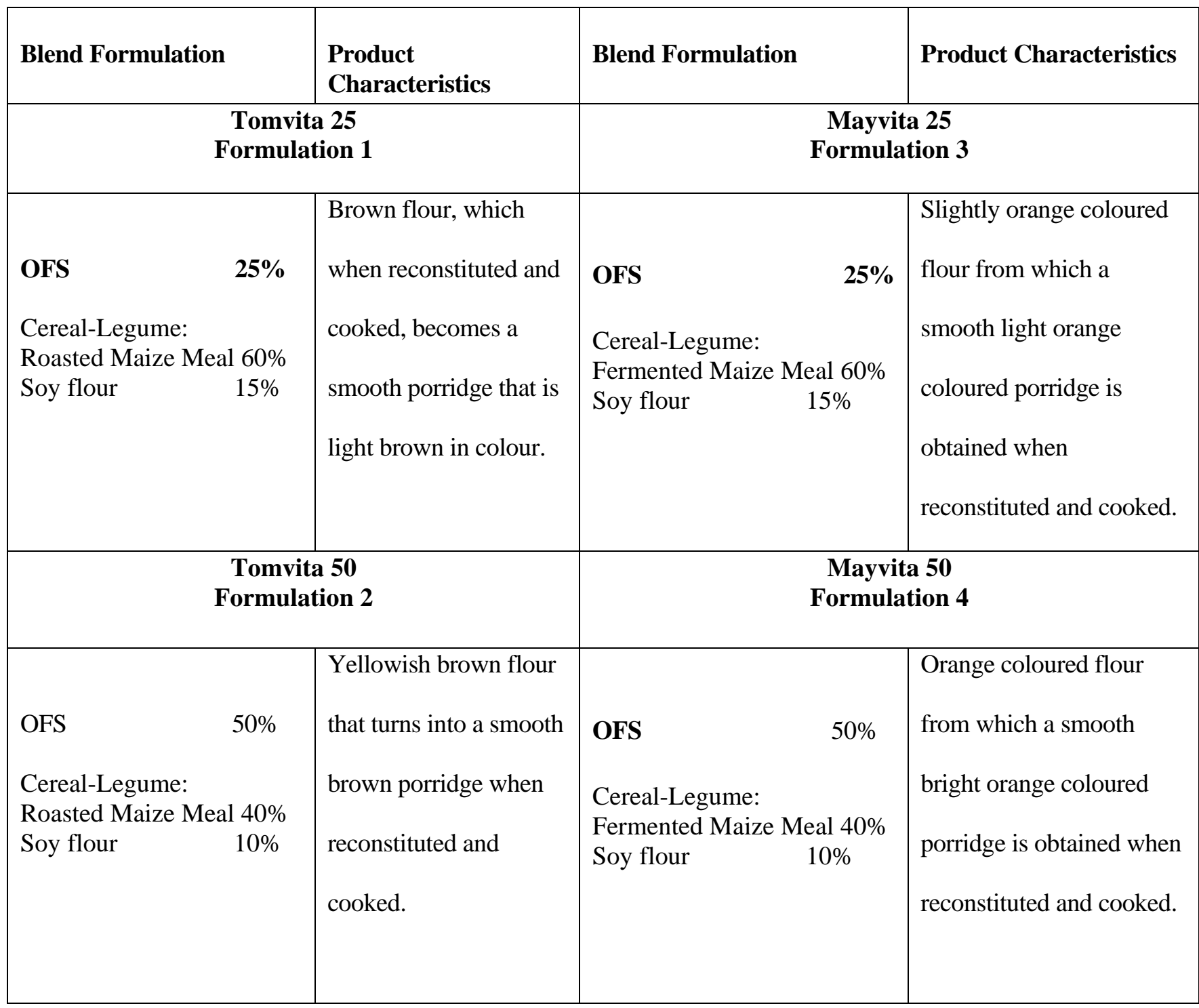

OFS= Orange flesh sweetpotato 


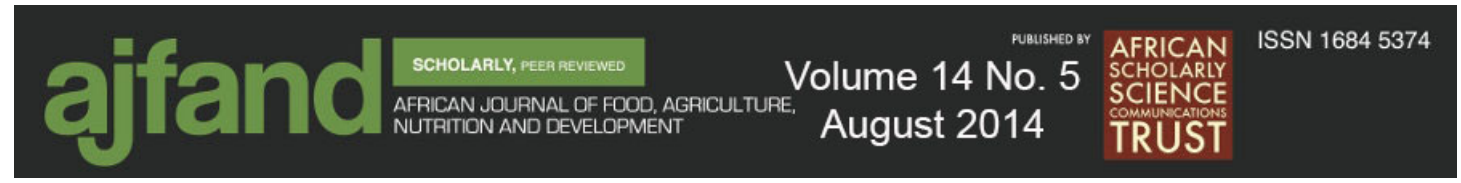

Table 3a: Triangle difference tests for OFS-based Roasted and Fermented maize meal weaning foods

\begin{tabular}{|c|c|c|c|c|c|}
\hline $\begin{array}{l}\text { Samples } \\
\text { compared }\end{array}$ & & $\begin{array}{l}\text { Identification of odd } \\
\text { sample }(p>0.05)\end{array}$ & $\begin{array}{l}\text { Degree of } \\
\text { difference }\end{array}$ & $\begin{array}{l}\text { Relative } \\
\text { acceptability }\end{array}$ & Comments \\
\hline $\begin{array}{l}\text { Roasted } \\
\text { maize meal } \\
\text { weaning } \\
\text { food }\end{array}$ & $\begin{array}{l}25 \% \text { OFS } \\
\text { Tomvita } \\
25\end{array}$ & $\begin{array}{l}\text { Positive } \\
\text { identification of odd } \\
\text { sample }\end{array}$ & Slight & $\begin{array}{l}\text { OFS product } \\
\text { more } \\
\text { acceptable }\end{array}$ & $\begin{array}{l}\text { Tasty product with } \\
\text { nice aroma, colour } \\
\text { and consistency. }\end{array}$ \\
\hline $\begin{array}{l}\text { Roasted } \\
\text { maize meal } \\
\text { weaning } \\
\text { food }\end{array}$ & $\begin{array}{l}\text { 50\% OFS } \\
\text { Tomvita } \\
50\end{array}$ & $\begin{array}{l}\text { Positive } \\
\text { identification of odd } \\
\text { sample }\end{array}$ & Much & $\begin{array}{l}\text { product more } \\
\text { acceptable }\end{array}$ & $\begin{array}{l}\text { Very colourful with a } \\
\text { sweet taste but has an } \\
\text { undesirable after- taste }\end{array}$ \\
\hline $\begin{array}{l}\text { Fermented } \\
\text { maize meal } \\
\text { weaning } \\
\text { food }\end{array}$ & $\begin{array}{l}\text { 25\% OFS } \\
\text { Mayvita } \\
25\end{array}$ & $\begin{array}{l}\text { Positive } \\
\text { identification of odd } \\
\text { sample }\end{array}$ & Much & $\begin{array}{l}\text { product more } \\
\text { acceptable }\end{array}$ & $\begin{array}{l}\text { Desirable appearance, } \\
\text { but has an off-flavour } \\
\text { and poor taste. }\end{array}$ \\
\hline VS & & & & & \\
\hline $\begin{array}{l}\text { Fermented } \\
\text { maize meal } \\
\text { weaning } \\
\text { food }\end{array}$ & $\begin{array}{l}\text { 50\% OFS } \\
\text { Mayvita } \\
50\end{array}$ & $\begin{array}{l}\text { Positive } \\
\text { identification of odd } \\
\text { sample }\end{array}$ & Very much & $\begin{array}{l}\text { product more } \\
\text { acceptable }\end{array}$ & $\begin{array}{l}\text { Poor aroma and taste } \\
\text { with an unattractive } \\
\text { bright yellow colour. }\end{array}$ \\
\hline
\end{tabular}




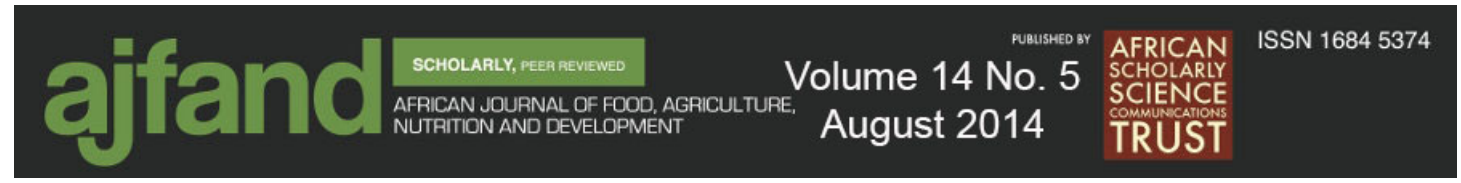

Table 3b: Mean sensory scores for OFS Roasted and Fermented Maize Meal weaning foods ${ }^{1}$

Roasted Maize Meal Weaning Food Fermented Maize Meal Weaning Food

Sensory $25 \%$ OFS

$50 \%$ OFS

$25 \%$ OFS

$50 \%$ OFS

Characteristics

Tomvita 25

Tomvita 50

Mayvita 25

Mayvita 50

$\begin{array}{lcccc}\text { Appearance } & 8.0 \pm 0.61^{\mathrm{a}} & 7.8 \pm 0.75^{\mathrm{a}} & 8.1 \pm 0.78^{\mathrm{a}} & 8.0 \pm 0.79^{\mathrm{a}} \\ & & & & \\ \text { Colour } & 7.9 \pm 0.66^{\mathrm{a}} & 7.8 \pm 0.83^{\mathrm{a}} & 8.1 \pm 0.97^{\mathrm{a}} & 8.1 \pm 0.90^{\mathrm{a}} \\ & & & & \\ \text { Aroma } & 7.7 \pm 0.83^{\mathrm{a}} & 7.3 \pm 0.69^{\mathrm{b}} & 7.2 \pm 0.81^{\mathrm{b}} & 6.7 \pm 0.86^{\mathrm{c}} \\ & & & & \\ \text { Consistency } & 7.7 \pm 0.69^{\mathrm{a}} & 7.7 \pm 0.85^{\mathrm{a}} & 7.7 \pm 0.77^{\mathrm{a}} & 7.4 \pm 0.87^{\mathrm{b}} \\ & & & & \\ \text { Taste } & 7.9 \pm 0.78^{\mathrm{a}} & 7.4 \pm 0.94^{\mathrm{b}} & 7.1 \pm 0.78^{\mathrm{b}} & 6.2 \pm 0.83^{\mathrm{c}}\end{array}$

Mouth-feel

$7.7 \pm 0.59^{\mathrm{a}}$

$7.7 \pm 0.86^{\mathrm{a}}$

$7.5 \pm 0.72^{b}$

$6.5 \pm 0.87^{c}$

Overall

$7.8 \pm 0.81^{\mathrm{a}}$

$7.3 \pm 0.71^{\mathrm{b}}$

$6.9 \pm 0.75^{\mathrm{b}}$

$6.2 \pm 0.97^{c}$

acceptability

${ }^{1}$ Means within a row not followed by the same superscript letter(s) are significantly different $(\mathrm{p}<0.05)$ 


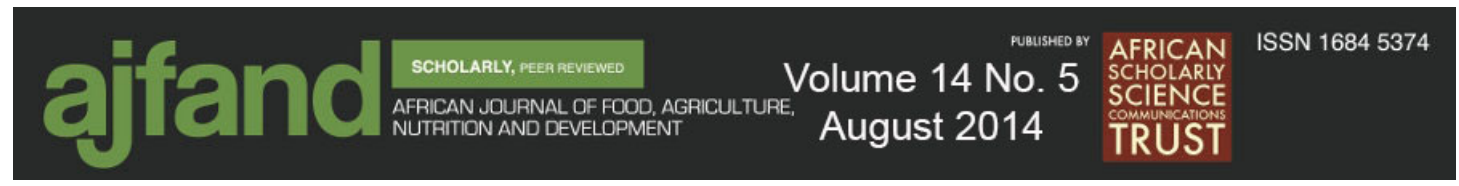

Table 4: Summary of overall acceptabilty scores, degree of liking and limiting sensory factors for the OFS Roasted and Fermented Maize Meal weaning foods

\begin{tabular}{|l|l|l|l|l|}
\hline \multicolumn{2}{|c|}{ Product } & $\begin{array}{l}\text { Acceptability } \\
\text { mean score }\end{array}$ & $\begin{array}{l}\text { Degree of } \\
\text { liking }\end{array}$ & $\begin{array}{l}\text { Limiting } \\
\text { sensory } \\
\text { factor(s) }\end{array}$ \\
\hline \multirow{2}{*}{$\begin{array}{l}\text { Roasted Maize } \\
\text { Meal (Tom } \\
\text { Brown)Weaning } \\
\text { Foods }\end{array}$} & $\begin{array}{l}\text { 25\% OFS } \\
\text { Tomvita 25 }\end{array}$ & $7.8 \pm 0.81$ & very much & none \\
\cline { 2 - 5 } & $\begin{array}{l}50 \% \text { OFS } \\
\text { Tomvita 50 }\end{array}$ & $7.3 \pm 0.71$ & moderate & Taste \\
\hline \multirow{2}{*}{$\begin{array}{l}\text { Fermented } \\
\text { Maize Meal } \\
\text { Weaning Foods }\end{array}$} & $\begin{array}{l}\text { 25\% OFS } \\
\text { Mayvita 25 }\end{array}$ & $6.9 \pm 0.75$ & moderate & Aroma \& taste \\
\cline { 2 - 5 } & Mayvita 50 & $6.2 \pm 0.97$ & slight & $\begin{array}{l}\text { Aroma, } \\
\text { consistency, } \\
\text { taste and } \\
\text { mouthfeel }\end{array}$ \\
\hline
\end{tabular}




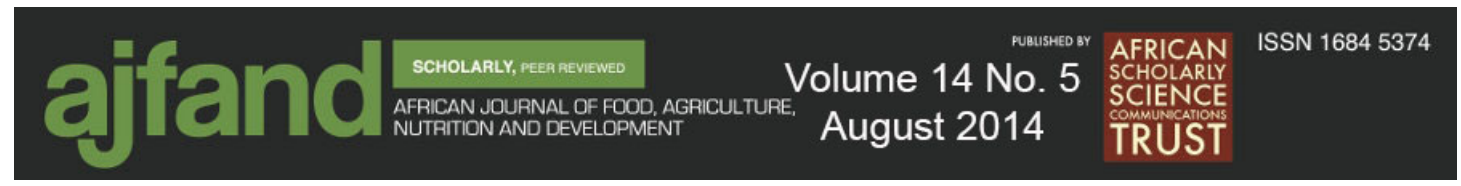

Table 5: Proximate composition, mineral and ß-Carotene content of OFS Fortified Roasted and Fermented Maize Meal weaning foods ${ }^{1}$

\begin{tabular}{|l|l|l|l|l|l|}
\hline Component & $\begin{array}{l}\text { Maize meal- } \\
\text { Soybean } \\
\text { only }\end{array}$ & $\begin{array}{l}\text { 25\% OFS } \\
\text { Tomvita 25 }\end{array}$ & $\begin{array}{l}50 \% \text { OFS } \\
\text { Tomvita 50 }\end{array}$ & $\begin{array}{l}\text { 25\% OFS } \\
\text { Mayvita 25 }\end{array}$ & $\begin{array}{l}\text { 50\% OFS } \\
\text { Mayvita 50 }\end{array}$ \\
\hline Moisture (\%) & 2.56 & 5.41 & 5.26 & 6.07 & 5.86 \\
\hline Ash (\%) & 1.98 & 2.21 & 2.54 & 2.32 & 2.54 \\
\hline Fat (\%) & 10.56 & 6.35 & 5.01 & 5.32 & 4.80 \\
\hline Protein (\%) & 17.10 & 14.97 & 12.13 & 15.02 & 13.42 \\
\hline $\begin{array}{l}\text { Carbohydrate } \\
\text { \%) }\end{array}$ & 67.80 & 71.13 & 75.08 & 71.29 & 73.39 \\
\hline $\begin{array}{l}\text { Energy (kcal) } \\
442.60\end{array}$ & 389.56 & 384.27 & 381.73 & 380.28 \\
\hline $\begin{array}{l}\text { Calcium } \\
\text { (mg/100 g) }\end{array}$ & 253.50 & 100.73 & 103.28 & 290.58 & 115.96 \\
\hline $\begin{array}{l}\text { Phosphorus } \\
\text { (mg/100 g) }\end{array}$ & 374.40 & 345.15 & 355.71 & 240.28 & 430.86 \\
\hline \begin{tabular}{l} 
Iron \\
\hline $\begin{array}{l}\text { ß-Carotene } \\
\text { (ug/g) }\end{array}$
\end{tabular} & 4.50 & 13.57 & 17.49 & 13.95 & 17.34 \\
\hline N/D & 66.47 & 115.55 & 55.18 & 104.78 \\
\hline Values are mean & & & & & \\
\hline
\end{tabular}

${ }^{1}$ Values are means of triplicate determinations

aSource: [2] Maize-soybean (Weanimix) used as a frame of reference 


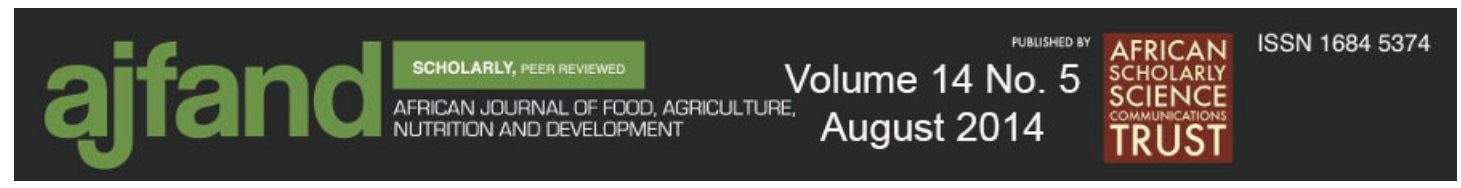

\section{REFERENCES}

1. FAO. United Nations Food and Agriculture Organization. Ghana Nutrition Profile. Nutrition and Protection Division. FAO, Rome, 2009.

2. Annan NT and WA Plahar Development and quality evaluation of a soyfortified Ghanaian weaning food. Food \& Nutr. Bull. 1995; 16 (3): 263-269.

3. Amagloh FK, Weber JL, Brough L, Hardacre A, Mutukumira AN and J Coad Complementary food blends and malnutrition among infants in Ghana: A review and a proposed solution. Scientific Research and Essays 2011; 7(9): 972-988.

4. WHO. Global prevalence of vitamin A deficiency in populations at risk 19952005. WHO Global Database on Vitamin A Deficiency. World Health Organization, Geneva, 2009.

5. Simler KR, Jacobs KL, MensahHomiah J, Randriamamonjy J, Wiesmann D and A Abdul-Razak Food-based Approaches to Reducing Micronutrient Malnutrition: An Impact Evaluation of the UNICEFICBD program in Savelugu Nanton District of Northern Ghana, 2005.

6. Hillocks RJ Farming for Balanced Nutrition: An Agricultural Approach to Addressing Micronutrient Deficiency among the Vulnerable Poor in Africa. Afric. J. Food, Agric., Nutri. Devel. 2011; 11(2): 4688-4707.

7. Tuskegee University. Nutritional and Economic Enhancement of Ghanaian Traditional Diets Using the Orange Flesh Sweetpotato (OFS) Products. Tuskegee University, GW Carver Agric. Exp. Sta. Sweetpotato Project Document, 2010.

8. Plahar WA, Bediako-Amoa B and D Fejer Functional properties of full-fat soyflour from soybeans grown in Ghana. I. Emulsifying properties. Ghana J. Agric. Sci. 1977; 10: 79.

9. Espinola N, Creed-Kanashiro H, Ugaz ME, van Hal $M$ and G Scott Development of a sweetpotato-based instant weaning food for poorly nourished children six months to three years old. CIP Program Report, 1997; 98: 295 - 302.

10. Low JW, Arimond M, OFSman N, Cunguara B, Zano F, and D Tschirley A Food-Based Approach Introducing Orange-Flesh Sweet Potatoes Increased Vitamin A Intake and Serum Retinol Concentration in Young Children in Rural Mozambique. J. Nutr. 2007; 137 (5): 1320-7.

11. Ghana Statistical Service (GSS). Noguchi Memorial Institute for Medical Research (NMIMR), ORC Macro. Ghana demographic and health survey 2003. Calverton, Maryland: GSS, NMIMR, ORC Macro, 2004. 
12. Ghana Statistical Service (GSS). Ghana Health Service (GHS), ICF Macro. Ghana demographic and health survey 2008. Accra, Ghana: GSS, GHS, ICF Macro, 2009.

13. Padmaja G Uses and nutritional data of sweetpotato. In: Loebenstein G and G Thottappillty (Eds). The Sweetpotato. The Netherlands: Springer, 2009: 189-223.

14. Woolfe JA Sweet potato: An untapped resource. Cambridge University Press, New York. 1991.

15. Lartey A, Manu A, Brown KH, Peerson JM and KG Dewey A randomized, community-based trial of the effects of improved, centrally processed complementary foods on growth and micronutrient status of Ghanaian infants from 6 to 12 months of age. Am. J. Clin. Nutr. 1999; 70(3): 391-404.

16. Lartey A, Manu A, Brown KH and KG Dewey Home, village and central processing of complementary foods: Results of a pilot intervention trial in Ghana. In: Fitzpatrick DW, Anderson JE, Labbe ML, eds. From nutrition science to nutrition practice for better global health: Proceedings of the16th International Congress of Nutrition, Jul 27-Aug 011997 Montreal, Canada. Canadian Federation of Biological Societies, Ottawa, ON, Canada, pp. 93-95.

17. Lartey A, Manu A, Brown KH, Peerson JM, and KG Dewey Vitamin A status of Ghanaian breast-fed infants 6-12 months fed improved complementary foods. FASEB J., 1998; 12(5): A648.

18. Lartey A, Manu A, Brown KH, Peerson JM and KG Dewey Predictors of growth from 1 to 18 months among breast-fed Ghanaian infants. Eur. J. Clin. Nutr., 2000; 54(1): 41-49.

19. Plahar WA, Leung HK and CN Coon Effects of dehydration and soy fortification on the physicochemical, nutritional and sensory properties of Ghanaian fermented maize meal. J. Food Sci. 1983; 48: 1255.

20. Plahar WA, Nti CA and NT Annan Effect of soy-fortification method on the fermentation characteristics and nutritional quality of fermented maize meal. Plant Foods for Human Nutri. 1997; 51:365-380.

21. Hagenimana V and C Owori Process of producing sweetpotato flour. Research for Development, Department for International Development, UKAID. 2000. http://r4d.dfid.gov.uk/PDF/Outputs/CropPost Harvest/R7036_sweetpotato_flour.pdf. Accessed January 2014. 


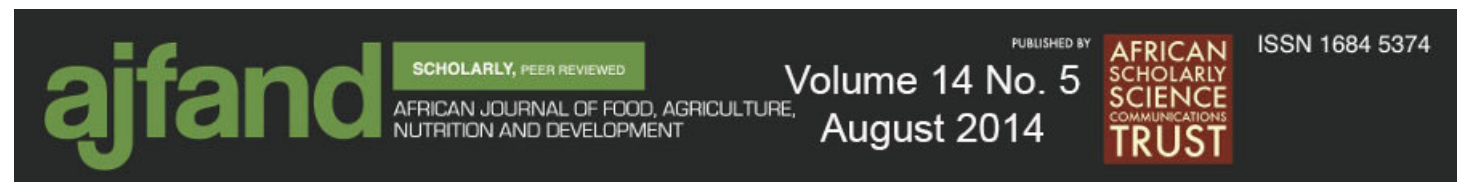

22. AOAC. Official Methods of Analysis. Association of Official Analytical Chemists, Washington, DC, 2000.

23. AACC. Approved Methods. American Association of Cereal Chemists, St Paul, MN, 1983.

24. Larmond E Laboratory methods for sensory evaluation of food. Ottawa, Canada: Canada, Dept. Agric. Pub. 1977; 1637:19-63.

25. Steel RGD and JH Torie Principles and Procedures of Statistics. A Biometrical Approach, $2^{\text {nd }}$ ed. Tokyo, Japan, McGraw-Hill Kogakusha, 1981.

26. Tanumihardjo SA Food-based approaches for ensuring adequate vitamin A nutrition. Comp. Rev. Food Sci. Food Safety. 2008; 7:373-381.

27. Tchum SK, Newton S, Tanumihardjo SA, Fareed KNA, Tetteh A and S Owusu-Agyei Evaluation Of A Green Leafy Vegetable Intervention In Ghanaian Postpartum Mothers. Afric. J. Food, Agric., Nutri., Devel. 2009; 9(6): 1294-1308.

28. WHO. Food Standards (Codex Alimentarius). Available at: http://www.who.int/foodsafety/codex/en/ with additional information at: http://www.fao.org/documents/show_cdr.asp?url_file=/docrep/w9114e/W911 4e00.htm . Accessed January 2014. 